\title{
Islamic Marketing Public Relations Strategy of Universitas Islam Sultan Agung Semarang
}

\author{
Made Dwi Adnjani ${ }^{1}$, Genta Maghvira², Trimanah $^{3}$ \\ Communcation Studies Department, Language and Communication Faculty, Universitas \\ Islam Sultan Agung (UNISSULA) Semarang ${ }^{1,2,3}$ \\ \{made@unissula.ac.id ${ }^{1}$, genta.maghvira@gmail.com² ${ }^{2}$ trimanah@unissula.ac.id ${ }^{3}$ \}
}

\begin{abstract}
The aims of this article is to describe marketing Public Relations activities undertaken by Universitas Islam Sultan Agung (UNISSULA). UNISSULA as a private university must work hard to be able to compete with other private university in obtaining students. Marketing Public Relations (MPR) which is a synergy between marketing activities and public relations strategy is carried out by UNISSULA in marketing the quality of learning products through Islamic Academic Culture (Budaya Akademik Islami/BUDAI). Through Islamic Marketing Public Relations, it is expected that UNISSULA will be able to strengthen its brand as an Islamic university that has a good reputation. The method used is descriptive qualitative with Relations Management theory from Ledingham. The conclusion of this article is in preparing Islamic marketing public relations planning, UPT Pemasaran dan Kehumasan UNISSULA make a Public Relations management relations with students, teachers / schools, parents, journalists and stakeholders through continuous communication and interaction. In addition, it also uses relationship management by bringing up statements from key figures who have visited Unissula or collaborating with UNISSULA. Digital Marketing Strategy is also used by UNISSULA to create engagement with prospective students, students and other stakeholders.
\end{abstract}

Keywords: Marketing, Public Relations, Strategy, Islamic Academic Culture (BUDAI).

\section{Introduction}

Universitas Islam Sultan Agung (UNISSULA) Semarang is a private Islamic university that is part of the Cooperation Agency for Private Islamic Universities in Indonesia (BKSPTIS). UNISSULA has a vision to become a leading Islamic university in building a best generation or khaira ummah, developing science and technology based on Islamic values and building civilization towards a prosperous society blessed by Allah SWT. within the framework of rahmatan lil'alamin. Building the Khaira Ummah generation has become UNISSULA's branding to penetrate the market and strengthen products or services. Branding is an attempt to evaluate products in the minds of consumers [1]. So far, UNISSULA has mastered the local market for the field of Islamic Higher Education Institutions, because 
Unissula has become an Islamic university that was founded in 1962. The name Sultan Agung is one of the national heroes who has greatly contributed to Indonesia as a religious king with superior character and capable of implementing life. having a religion through acculturation that can be accepted by the community, UNISSULA uses the name of this hero as the name of the university. Therefore, it is hoped that UNISSULA will continue to ignite the spirit of the nation's struggle in education with Islamic values with Islamic Academic Culture (BUDAI). One of the concepts to promote Islamic values is used in promotional activities at UNISSULA through marketing public relations.

Public Relations marketing activities of the Public Relations strategy consist of three tactics, namely to pull (pull strategy), to push (push strategy) and efforts to influence or create favorable public opinion and public relations should be able to influence public awareness [2]. Public Relations itself is a mechanism that can connect producers with consumers or organizations, with the public effectively and can create organizational dependence with the public [3]. This shows that the UPT Marketing and Public Relations in higher education is required to always work hard in realizing the goals of the organization.

The higher education database (PDDikti) in higher education statistics for 2018 reports that there are around 1,472,156 new students enrolling in both public and private universities. This number increased by about $2.4 \%$ from 2017 which amounted to $1,437,425$. This can be interpreted that the interest of Indonesian students to continue their education to the tertiary level. Private universities (PTS) have an important role in providing higher education services. This is reflected in higher education data in 2018 that private universities received around 921,359 (62.6\%) new students compared to State Universities (PTN) which accepted around 550,797 (37.4\%) new students [4]. Amid the optimism of PTS in meeting the target number of new students, the COVID-19 pandemic suddenly appeared and reversed all predictions. A number of PTS managers stated that there had been a decrease in registrants compared to the same time as student admissions last year. During a pandemic, marketing and promotional activities based on physical encounters such as educational exhibitions and school visits is practically impossible. Therefore, private universities must immediately adapt to overcome this situation. Private universities are required to think creatively and immediately innovate, especially in the marketing sector.

Therefore the problem formulation in this article is How the Marketing Public Relations strategy carried out by Sultan Agung Islamic University (UNISSULA) Semarang. This article aims to describe the marketing activities of Public Relations conducted by UNISSULA. The role of marketing and Public Relations in a high education organization is one of the keys to achieving the goals of an institution. Dozier mentions the role of Public Relations with four categories, namely expert presciber, problem solving, process facilitator, communication facilitator and communication technician. The first three roles are usually owned by those at the manager level or known as managerial roles. While the latter is a technical role. However, the position of Public Relations in an institution is very important even with the human heart [5] because it specifically must be able to determine all communication activities and as a center of information for the publics.

\section{Literature Review}

Philip Kotler [6] came up with the mega marketing concept which is a combination of public relations and the marketing mix. In subsequent developments, Thomas L. Harris popularized the term marketing public relations, as stated by Ruslan [7] that Public Relations 
marketing is the process of planning and evaluating programs that stimulate customer sales. Public Relations work programs must be planned carefully and carefully [8] so that real results will be obtained. Without planning, public relations practitioners will easily lose direction in setting goals. PR marketing planning is an application of the PR operational process in an effort to solve marketing problems. PR marketing planning is included in PR planning in supporting marketing goals and strategies. PR marketing strategy can be understood by outlining three main elements, namely strategy, marketing and PR.

Strategy comes from a derivative of the Greek word "strategos" which can be translated as military commander in the democratic era of Athens. Meanwhile, the American Marketing Association or AMA (The American Marketing Association) in Morissan [9] defines marketing as a process of planning and implementing the conception, price, promotion and distribution of ideas, goods and services to create exchanges that satisfy individual and organizational goals. According to Cutlip Center and Broom [10] PR is a management function that assesses public attitudes, identifies policies and procedures of a person or organization in the public interest, and plans and carries out a program of activities to gain public understanding and support.

The Operational Process of Cutlip Center and Broom PR as explained by Thomas L. Harris in the book The Marketer's Guide to public Relations [11], that PR marketing planning is inseparable from an operational process which consists of: (1) Defining PR problems. This stage aims to find data and facts in the field in an effort to determine PR problems. At this stage, the operation includes steps in an effort to find and collect data carried out by PR in the form of public opinion, public attitudes, and public behavior; (2) Planning and Programming, this stage greatly determines the success or failure of PR work as a whole, (3) Taking Action and Communicating is a stage of implementing PR activities in accordance with the formulated planning and program; (4) Evaluating the Program, the last stage is carried out to find out whether the implementation is based on the plan or not and whether it needs to be changed or not. The purpose of this evaluation is to find out whether PR activities are actually being carried out according to the planning based on the results of data and facts in the field. The theory of four stages in the Public Relations process is important because it is related to the basic function of Public Relations, namely communication activities that connect organizations with the public.

John Ledingham in Heath [12] defines the organization's relationship with the public through the theory of relationship management processes and focuses on discussing the relationship management process between the organization and the public as a situation in which the actions of both parties can have an impact on the economic, socio-cultural or political aspects of each. each party. The relationship that is built with the public in planning a marketing PR program is to build positive relationships with reciprocal two-way communication. Relationships are the core of Public Relations activities, these relationships are represented through patterns of interaction, exchange transactions and relationships between organizations and the public. This is in line with the statement of Cutlip, Center and Broom [13] that Public Relations is a management function that builds and maintains a good and beneficial relationship between an organization and PR using sound and ethical research and communication as its main tools. Relationship Management Theory explains that communication is placed as a tool to build relationships and programs are evaluated based on their impact on the relationship between organizations and the public [14]. Communication acts as a tool for initiating, developing and maintaining relationships with the public. In the planning process of the marketing PR program, communication carried out by the Marketing and Public Relations Technical Implementation Unit of UNISSULA with students, teachers 
and the school becomes the basis for making planning stages with reciprocal communication because without good communication the marketing PR program cannot be carried out. The aspect of emotional closeness that is built is very important in establishing a relationship between the two parties. This is in line with Grunig [15] about the two-way simmetric model, where the focus of Public Relations activities is to build relationships and mutual understanding, where organizations consider the public not limited to passive recipients, but that the public can act as a source information. The two-way symmetrical model describes a public relations model that operates on the basis of research and uses communication to increase understanding with stakeholders.

Relationship management theory is categorized into three types of relationships, namely personal, professional and community realizations [16]. In the context of this research, public relations establish personal relationships with students and guidance and counseling teachers in schools in an effort to build emotional closeness between the two parties. Public Relations also establishes relationships with parents, government and journalists. Community relations are also built with public and private universities as competitors. Communication is a tool for dialogue between institutions and the public, communication becomes a means of negotiation and compromise in an effort to build relationships. This theory creates a take and give atmosphere in which institutions and the public strive to reach consensus and collaboration. Public relations must be able to act as a co-creator in the PR program planning process and also in building relationships with the public. This relationship management is the basis for planning the Marketing Public Relations program.

\section{Method}

The type of research in this article is descriptive qualitative. The data collection technique was carried out through in-depth interviews with the Head of the Marketing and Public Relations Unit, the head of the marketing division, the head of the public relations division and the head of the creative content division at the UPT Marketing and Public Relations Unit of UNISSULA. Observations were made with in-depth observations of marketing public relations activities at UNISSULA. In addition, literature studies were carried out by reviewing books on public relations, reviewing scientific journals and articles related to Marketing Public Relations materials. Data analysis is obtained by reviewing all available data from various sources, then studying and reducing the data by making abstractions, then arranging them in units and grouping them according to the research problem.

\section{Results and Discussion}

Sultan Agung Islamic University is a private university built with Islamic identity, so that what is built and displayed in PR marketing activities is its Islamic identity. Logos, ad design, student talent in advertisements and presentation activities must be based on Islamic values. Ideally, image and identity must be in harmony, because this identity will bring up perceptions in relation to branding and the image of the institution in the minds of the public. Logos, dani clan designs are part of a sign that apart from having philosophical values also distinguishes UNISSULA from other private universities. According to Argenti [17], corporate identity is. the manifestation and reality of the company as conveyed through the company name, logo, motto, service products, buildings, stationery, uniforms, and tangible evidence items created by the organization and communicated to various publics. Punlik will form perceptions based 
on messages sent by the company in real form. This perception will later form the image of the institution. This identity originates and is imposed by the institution, meaning that UNISSULA controls Islamic identity in the public mind and at UNISSULA this activity is carried out through marketing public relations activities.

\subsection{Marketing Public Relations UNISSULA}

Based on the results of observations and in-depth interviews, the marketing public relations planning process at UNISSULA is inseparable from the operational processes of PR Cutlip, Center, and Broom in Harris [18], namely:

\section{a) Stages of Collecting Data and Field Facts}

This stage begins by collecting data from the evaluation of the previous year's PR Marketing activities. From the evaluation results it can be seen which activities are effective and which are not. The results of this evaluation are carried out through formal research every year, and informally carried out by gathering events, visits and interviews with career guidance teachers in schools. Through this activity, UNISSULA asked for opinions on what kind of PR marketing activities the school wanted, in addition to conducting informal interviews with high school, vocational high school students, Madrasah Aliyah and prospective new students, sometimes also holding discussions with related journalists. the trend of PR marketing activities of educational institutions, especially universities. Besides that, it also held discussions with the faculty promotion team so that there was synergy between PR marketing activities at the university level and the faculty level. Every exhibition, event such as the Unissula Science and Arts Festival (FISSI), open houses and presentations to schools as well as UNISSULA asks for feedback on activities carried out through filling out a questionnaire. During the Covid-19 pandemic, because it was impossible to carry out presentations, exhibitions and so on, UNISSULA held an Online Gathering and Workshop with the Central Java Guidance and Counseling Teacher Association (MGBK).

\section{b) Planning Public Relations Marketing Program}

Based on the results of collecting data from the field and evaluating PR marketing activities, the head of the Marketing Unit and the Head of the Division and the staff make a PR marketing program and its budget through the SP4 (Program Planning and Budget System) meeting. This meeting is usually held towards the end of the fiscal year, in an effort to make a budget plan for the next year. After completing his SP4, he will be consulted with the Vice Chancellor for Student Affairs and the Deputy Chancellor for Finance and Administration and the Head of the Finance Bureau. After the process at the university level is complete, the university will consult with the Sultan Agung Waqaf Foundation for approval of work programs and budgets.

\section{c) Implementation of Marketing Public Relations Program}

The implementation of the UNISSULA marketing PR program is carried out with the assistance of female students who are members of the junior marketer, faculty promotion team, and also alumni. The implementation of the marketing PR program is adapted to the situation in the field and coordinated with the target market. For roadshows or presentations to 
schools, coordination is usually carried out since September in coordination with the school authorities to determine the implementation time. For advertisements in print, electronic and virtual media, the head of the creative content division always coordinates with the Vice Chancellor for Student and Alumni Affairs and also with the person in charge of New Student Admissions.

\subsection{Digital Marketing Public Relations UNISSULA}

In today's era of information technology, the internet has enhanced two-way communication between organizations and the public. Effective online media focuses on the audience's needs, meaning that various information needed by students should be in online media. Online media represents an exchange of paradigms in corporate communication, opening the door to full two-way communication between companies and stakeholders. The presence of social media in marketing in the digital era will have an impact on more interactive communication and build stronger engagement with the target market. The internet or online media not only has an impact on opening two-way communication and engagement but also has an impact on long-term image and reputation in the minds of the public. The presence of social media in marketing in the digital era can be seen from two sides, namely the advertiser side and the social media user side. From the advertiser's side, social media offers a variety of content, not only in the form of text, but also audio, visual and a combination of the three. The production of advertising and the use of social media also tends to cost less than mass media. In addition, advertising on social media can be well analyzed to find out how many clicked on the ad, from which area and when or at what time it can be well known. Especially during the Covid-19 pandemic, where it was impossible to do direct marketing in schools through roadshows and exhibitions, digital marketing became a very appropriate marketing strategy for UNISSULA.

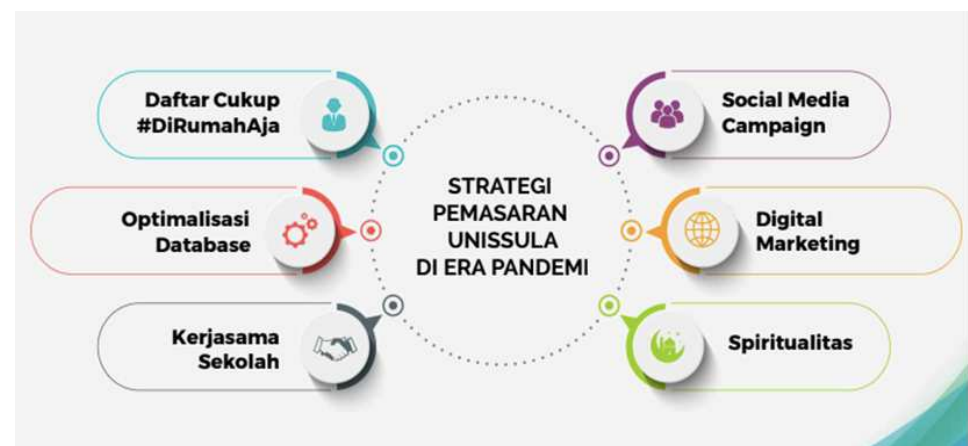

Fig. 1. UNISSULA's Digital Marketing Public Relations Strategy during the Pandemic Source: UNISSULA Public Relations and Public Relations Unit

Social media is a medium on the internet that allows users to represent themselves and interact, cooperate, share, communicate with other users, and form a virtual bond [19] The presence of social media provides an alternative choice for UNISSULA by using digital marketing through campaign activities on social media, especially during this pandemic the use of digital marketing public relations is an alternative to communicate more interactively and build virtual relations between universities and the public. Audiences on social media move very fluidly [20] Structurally, the UPT Marketing and Public Relations Unit of 
UNISSULA has a special section that handles the web and social media by adding one more division, namely the creative content division so that maintenance for the web and social media can be maintained. Internet and social media also allow communication practices within the reach of audiences. Reaching social media and a much larger network of users is the key to success in building good understanding between UNISSULA and its public. Especially because UNISSULA puts forward self-presentation as an Islamic university so that when interacting with stakeholders it presents a self-image based on the vision and mission of the institution through the tagline Bismillah to build a generation of khaira ummah.

In marketing PR activities, UPT Marketing and Public Relations becomes an actor who represents the institution and tries to manage the message and impression as a private Islamic university that is different from other universities. Through PR marketing activities, UNISSULA public relations presented themselves as higher education that synergizes Islamic values in various academic and non-academic activities, integrates Islamic values with various disciplines developed at UNISSULA and displays Islamic values in the behavior of leaders, lecturers, employees, students and alumni through verbal and non verbal symbols. This has become the positioning of UNISSULA as a private Islamic university in Central Java with its Islamic Academic Culture (BUDAI). This is in line with the principle of Public Relations communication on social media in an Islamic perspective according to Kriyantono [21] namely Qaulan Layyinan, which puts forward solutive persuasion with gentle, nonprovocative words, does not drop the dignity of others so that it can touch hearts.

\section{Evaluation of Marketing Public Relations Program}

The evaluation stage is carried out at the end of the fiscal year, evaluation is carried out based on the activities, results and benefits. One of them is by evaluating the event held by the Marketing and Public Relations Unit. In addition, evaluation is also carried out on social media, to evaluate the website, who reads news and announcements on the website, and the extent to which the publications carried out are responded to or responded to by readers and audiences on social media [22]. From the results of this evaluation, this will be the basis for the improvement of the events held and also the basis for the PR marketing work program in the coming year.

\subsection{Impression Management of UNISSULA}

Impression management theory is known as organization public relationship (OPR) theory. In public relations practice, communication is shown to maintain goodwill that can be felt by communication participants, and ensuring a balance of interests between the two [23]. Impression management is an organization's effort to build a relationship with its public to create a positive relationship between two directions, namely between the organization to the public and the public to the organization. UNISSULA in practice also create positive relationships by building long-term and sustainable communication activities. The Covid-19 pandemic is not an obstacle to staying in touch with the public or its stakeholders. Through live broadcast activities on IG everyday and webinars held with the theme Gathering with guidance and counseling teachers, it shows that UNISSULA tries to continue to build sustainable and long-term relationships. In the process of UPT Marketing and Public Relations impression management through personal relationships, professional relations and community relations based on the perception that organizations support the interests of the community through communication or program driven. 


\section{Conclusion}

a) The concept of Islamic marketing PR for UPT Marketing and Public Relations UNISSULA is a PR marketing activity that emphasizes Islamic values and spirituality which contain the values of da'wah and Islamic syiar in increasing the number of prospective students, building a positive image and promoting the formation of noble morals.

b) Planning for the UNISSULA Marketing PR program in the process cannot be separated from the operational process of Cutlip, Center and Broom which begins with 1) defining PR problems; 2) planning and programming; 3) taking action and communicating; and 4) evaluating the program. In planning and implementing marketing strategies, PR UNISSULA is building relationship management with stakeholders through continuous and long-term communication activities.

c) Implementation of PR Marketing activities is direct and through media. During the Covid-19 pandemic, the use of digital marketing and social media campaigns was more intense because visits to schools as roadshows were not possible. In the implementation of marketing PR activities, UPT Marketing and Public Relations becomes a representative of the institution by presenting images through verbal and non-verbal messages as a higher education institution based on Islamic values with the tagline Bismillah Building Generation of Khaira Ummah, and religious jargon Yes, Achievement OK.

\section{Acknowledgments}

Thanks are given to the Dean of the Faculty of Languages and Communication Sciences who allowed to conduct this internal research, thanks to the Institute for Research and Community Service (LPPM) UNISSULA and specifically to the UPT Marketing and Public Relations UNISSULA which allowed to conduct research and observations on Marketing Public Relations activities.

\section{References}

[1] P. A. Argenti, Komunikasi Korporat, Jakarta: Salemba Humanika, 2010.

[2] E. Arianto, "http://strategika.wordpress.com/2007/06/24/pengertian-strategi.," 2406 2007. [Online]. [Accessed 21 Juni 2020].

[3] M. Chatamalah, "Strategi "Public Relations" dalam Promosi Pariwisata: Studi Kasus dengan Pendekatan "Marketing Public Relations" di Provinsi Banten," vol. 9, no. 2, 2008.

[4] Center, Cutlip, Effective Public Relations, New Jersey: Prentice Hall, 2013.

[5] Grunig, J. \&. G. L. Grunig, Model of Public relations and Communication Excellent in Public Relations and Communication Management, Michigan: Hilssdale, 1992.

[6] M. Chatamallah, "Strategi "Public Relations" dalam Promosi Pariwisata: Studi Kasus dengan Pendekatan "Marketing Public Relations" di Provinsi Banten," vol. 9, no. 2, 2008.

[7] N. Yulianita, Dasar-Dasar Public Relations, Bandung: LAb. Multimedia Fikom UNISBA, 2001. 
[8] Soemanegara, Strategic Marketing Communication: Konsep Strategis dan Terapan, Bandung: Penerbit Alfabeta, 2012.

[9] N. Yulianita, Dasar-Dasar Public Relations, Bandung: Lab. Multimedia Fikom Unisba, 2001.

[10] P. K. S. P. TInggi, Statistik Pendidikan Tinggi Indonesia tahun 2018, Jakarta: Pangkalan Data Pendidikan Tinggi, 2018.

[11] P. I. Dikti, Statistik Pendidikan Tinggi Indonesia. Pusdatin Kemenristek Statistik Pendidikan Tinggi 2018, Jakarta: Pusdatin Iptek Dikti, Setjen Kemenristek Dikti, 2018

[12] M. Chatamallah, "Strategi "Public Relations" dalam Promosi Pariwisata: Studi Kasus dengan Pendekatan "Marketing Public Relations" di Provinsi Banten," Mediator, vol. 9, no. 2, pp. 393-394, 2008.

[13] N. Yulianita, Dasar-Dasar Public Relations, Bandung: Lab. Multimedia Fikom Unisba, 2001.

[14] P. K. Dikti, Statistik Pendidikan Tinggi Indonesia 2018, Jakarta: Pusdatin Kemenristek Dikti, Setjen Kemenristekdikti, 2018.

[15] N. Yulianita, Dasar-Dasar Public Relations, Bandung: Lab. Multimedia Fikom Unisba, 2001.

[16] P. Kotler, Manajemen Pemasaran Jilid 1, Jakarta: PT INDEKS, 2005.

[17] Ruslan, Manajemen Humas dan Manajemen Komunikasi: Konsepsi dan Aplikasi, Bandung: Simbiosa Rekatama, 1998.

[18] F. Jeffkins, Public Relations Edisi Kelima, Jakarta: Erlangga, 2003.

[19] Morissan, Perikalanan Komunikasi Pemasaran Terpadu, Jakarta: Kencana Prenada Media, 2010.

[20] R. L. Heat, Encyclopedia of Public Relations, London: Sage Publications, 2005.

[21] R. Kriyantono, Teori Public Relations Perspektif Barat dan Lokal: Aplikasi Penelitian dan Praktek, Jakarta: Prenada Media Group, 2014.

[22] T. L. Harris, The Marketer's Guide to Public Relations, New York: JOhn Wiley \& Sons, Inc., 1991.

[23] R. Nasrulloh, Media Sosial Perspektif Komunikasi, Budaya dan Sosioteknologi, Jakarta: Kencana Prenada Media, 2015. 